
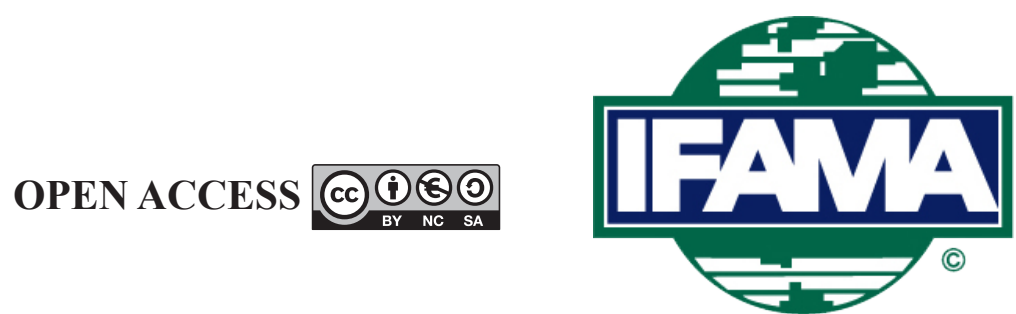

International Food and Agribusiness Management Review

Volume 23, Issue 3, 2020; DOI: 10.22434/IFAMR2019.0178

Received: 31 October 2019 / Accepted: 30 April 2020

\title{
Relationship quality and supplier performance in food supply chains \\ RESEARCH ARTICLE
}

\author{
Nic Lees ${ }^{\circledR a}$, Peter Nuthall ${ }^{\mathrm{b}}$ and Mark M.J. Wilson ${ }^{\mathrm{c}}$ \\ ${ }^{a}$ Senior Lecturer, ${ }^{b}$ Associate Professor, ${ }^{c}$ Senior Lecturer, Faculty of Agribusiness and Commerce, \\ Lincoln University, Ellesmere Junction Road, Christchurch, 7647, New Zealand
}

\begin{abstract}
The importance of procurement relationships in food supply chains is increasing in importance due to issues of food safety, food security, changing consumer preferences, ethical concerns and greater awareness of the environmental impact of food production. Despite the considerable research on buyer-seller relationships in the marketing and management literature, only a small proportion of this has focused on procurement relationships between producers and buyers in food supply chains. Hence, this paper specifically focuses on examining the impact of relationship quality on supplier performance in the context of food supply chains. The theoretical framework is derived from the tenets of the resource-based view and the relational view of firms. Using this framework, the definition, measurement and structural dimensions of relationship quality is established in the context of food producers and buyers. This construct is then tested in relationship to supplier performance. Utilizing data from a mail survey of 954 red meat producers in New Zealand, the model of supplier-buyer relationship quality and its effects on supplier performance is tested using structural equation modelling. The results demonstrate that relationship quality is an essential factor in procurement relationships with suppliers in food supply chains and shows that, as hypothesized, higher quality relationships lead to positive performance outcomes. The results support the theoretical framework indicating that relationship quality, conceptualized and defined in this context, is indeed a valuable relational resource due to its impact on supplier performance. Managerially, this resource can be manipulated to improve supplier performance, and hence potentially provide firms with competitive advantage that has high replication barriers.
\end{abstract}

Keywords: relationship quality, supplier performance, resource-based view, food supply chains JEL code: Q13

(®Corresponding author: nic.lees@lincoln.ac.nz 


\section{Introduction}

The relationship between buyers and sellers has long been recognized as essential to business performance (Anderson and Narus, 1984; Dyer and Singh, 1998; Ganesan, 1994; Geyskens et al., 1996; Morgan and Hunt, 1994). For example, Lambert (2006: 1) states, '...one of the most significant paradigm shifts in modern business management is that individual businesses no longer compete solely as autonomous entities but rather as supply chains'. In this context, the success of an individual business often depends on their ability to manage and integrate a complex network of relationships (Choi and Wu, 2009; Kim et al., 2010; Touboulic and Walker, 2015).

Though procurement relationships are known to be important in food supply chains, less is known about the nature of these relationships (Stevenson et al., 2016). Procurement and purchasing relationships in this context have specific characteristics due to the complexity that arises as a result of the features of food production, processing, distribution and consumption (Beske et al., 2014; Govindan, 2018; Matopoulos et al., 2007; Rueda et al., 2017; Trienekens et al., 2012). Such features include shelf life constraints, food safety, variable quality and quantity of supply. These arise from the biological nature of food products which are affected by seasonality, weather, the environment, pests and other factors (Van der Vorst et al., 2002).

There is also frequently, a large and fragmented supply base within the agricultural sector (Ateş et al., 2015; Brooks et al., 2017; Haasis and Ldic, 2008; Touboulic and Walker, 2015) with suppliers often being individual farmer owner-managers rather than companies or corporations. As a result, managing the procurement and purchasing operations of food supply chains can be costly and complex (Beske et al., 2014). Added complexity comes from food safety (Rábade and Alfaro, 2006) and environmental sustainability concerns that are important to stakeholders and consumers (Beske et al., 2014; Govindan, 2018; Matopoulos et al., 2007; Rueda et al., 2017).

Combined with this are significant changes occurring in food supply chains. For example, a substantial amount of food production has moved from primarily undifferentiated commodity goods to products with specific value-added attributes for defined market segments (Baker and Smyth, 2012; Folkerts and Koehorst, 1998; Stevenson et al., 2016). There are a number of forces driving these changes such as a growing population of affluent consumers, changing consumer preferences, development of information systems, growing environmental and ethical concerns, globalization, and more recently, the re-imposition of tariffs, duties and other trade barriers (Federal Reserve, 2019; Govindan, 2018; Li et al., 2014; Young and Hobbs, 2002). Ensuring a secure supply of differentiated value-added food products can be problematic. Hence, increased pressure is put on supplier performance as food products have become more differentiated. Yet, not all suppliers have the ability or willingness to meet these higher product specifications, so individual suppliers are less able to be substituted which increases transaction cost especially search and monitoring costs (Baker and Smyth, 2012; Duffy and Fearne, 2004).

These issues highlight the complexity and challenge of managing procurement and purchasing relationships with suppliers in food supply chains (Beske et al., 2014). Indeed, a number of authors have identified the need for more research in this area (Beske et al., 2014; Matopoulos et al., 2007). Brooks et al. (2017) and Gorton et al. (2015) both identify a lack of published research on buyer-supplier relationships in food supply chains. Furthermore, Gorton et al. (2015: 7) observe that the '...literature on buyer-supplier relationships overwhelmingly draws on manufacturing and retail cases...' and has mostly relied on data and examples from North America and Western Europe. Cannon et al. (2010) call for the examination of buyer trust and supplier performance in a broader range of geographical contexts. Furthermore, a meta-analysis of the empirical studies on relationship marketing by Palmatier et al. (2006) exemplify the situation. They found that none of the empirical studies involved the food industry context or biological products. Finally, most studies have evaluated relationships between organizations rather than organizations and individual actors (Parsons, 2002). Relationships between individuals and organizations can involve a significant power 
imbalance, and individuals may make decisions based on personal preferences rather than according to organizational policy or objectives.

This study attempts to address these gaps in several ways. Firstly, the structural dimensions and measurement of relationship quality and supplier performance are explored in the context of relationships within food supply chains. Secondly, using the theoretical framework of the resource-based view (RBV) (Barney, 1991) and the relational view (RV) (Dyer and Singh, 1998), the relevance of these theories applied to the context of procurement relationships in food supply chains is examined. In particular, the framework is tested in terms of the effect of relationship quality on supplier performance. Thirdly, this research is also undertaken in the underexplored context of food supply chains that involve perishable biological products and in a different geographical context than the majority of research into buyer-seller relationships. Fourthly, it also involves asymmetric power relationships between buyers and suppliers that are primarily individual/company dyads. Finally, the New Zealand context provides some interesting aspects of the research. This is the result of the free-range and grass-fed production systems, the features of red meat products, the heavy reliance on export markets and the consequent geographical distance between production and consumption (Clemens and Babcock, 2004; Grunert et al., 2005; Lees and Nuthall, 2015; Lees and Saunders, 2015; Trienekens et al., 2018).

Hence, the specific research objectives are:

- Adapt, develop and validate measures for relationship quality and supplier performance that can be used within the particular context of supplier-buyer relationships in food supply chains.

- Empirically test and validate the theoretical framework utilizing the RBV and RV to describe the relationship between buyers and their suppliers in food supply chains and the effects on supplier performance.

The remainder of the paper proceeds with the following structure. Firstly, the paper outlines the process and logic of the theoretical model derived from the resource-based and relational exchange views. Next, the structural dimensions of relationship quality and supplier performance in the context of food supply chains are discussed. Then the specific constructs used in the research are described. The analysis and results describe the characteristics of the sample, the results of the exploratory factor analysis, and the testing of the measurement model using confirmatory factor analysis. Structural equation modelling identifies and tests the significance and explanatory power of the paths between the variables which are used to test the research hypotheses. The paper concludes with the discussion of the results and conclusions that can be drawn from data. This section also describes the significance of the results and identifies the contribution of the research to the understanding of buyer-supplier relationships and their impact on performance. This section also relates the results to previous studies, as well as the theoretical and managerial implications of the research. Finally, the limitations of the study and potential areas for future research are discussed.

\section{Theoretical framework}

The RBV and the RV have been used as the theoretical basis for examining relationship quality and supplier performance in food supply chains as they provide a basis for evaluating relational resources and their impact on the supplier performance (Shih, 2017; Steiner et al., 2017). The RBV describes the firm as a collection of productive resources and proposes that they are managed and organized in order to achieve an ongoing competitive advantage. It has been suggested that this can be achieved through a firm owning or having access to resources that are valuable, rare, difficult to imitate and deployable by the organization (Barney, 1991). Furthermore, companies have realized that good relationships often offer the best route to obtaining these valuable external resources (Conner, 1991). Added to this, the RV emphasizes that a firm's relationships, in-of-themselves, can be seen as inimitable value-generating resources (Dyer and Singh, 1998; Gulati et al., 2000). Therefore, buyer-seller relationships and the quality of these relationships becomes a central focus of a firm's ability to gain competitive advantage (Barney, 2012; Gadde and Snehota, 2000; Lechner and Dowling, 2003; Morgan and Hunt, 1999). There is considerable literature on the RBV and 
competitive advantage including relationship quality and its impact on competitive advantage (Kannan and Tan, 2006; Kull et al., 2016). The theoretical model (Figure 1) draws on the RBV and RV theories by defining relationship quality as a relational resource.

More specifically relationship quality provides a measure of the relational resources a buyer has with their suppliers. There is a wide range of literature that identifies a link between relationship quality and aspects of the performance of the buying firm. These include such things as operational performance (Fynes et al., 2008), product quality (Chen et al., 2017) and innovation (Kim et al., 2017; Gellynck et al., 2011). This literature often fails to define how the quality of relationships delivers these performance outcomes.

As with any resource, relational resources do not by themselves improve a firm's performance and competitive advantage. The theoretical model (Figure 1) proposes that it is higher performing suppliers that enable buyers to improve their performance and therefore competitive advantage (Nyaga and Whipple, 2011). Consequently, supplier performance is defined as the 'resource impact' that provides the buyer with performance benefits and competitive advantage (Shin et al., 2000). It proposes that relational resources impact a firm's competitive advantage through the resource impact, in this case, supplier performance (Li et al., 2012; Yang and Zhang, 2017).

\subsection{Relational resources}

Based on the RBV and the RV, this research seeks to understand the impact of relational resources on the performance of suppliers. It is argued that the 'quality' of these relational resources is the key influencer, with higher quality relational resources leading to higher performance. This involves exploring the definition, measurement and structural dimensions of relationship quality in the context of food supply chains.

In terms of defining relationship quality, Lages et al. (2005: 1041) argue that it is a construct that, '....reflects the overall strength' of a relationship. It is commonly defined as a higher order construct made up of a number of distinct, but related, dimensions (Crosby et al., 1990; Dwyer et al., 1987; Kumar et al., 1995a; Lages et al., 2005). The most commonly cited sub-dimensions of relationship quality are trust, commitment and satisfaction (Athanasopoulou, 2009; Crosby et al., 1990; Dorsch et al., 1998; Hewett et al., 2002; Schulze et al., 2006; Ulaga and Eggert, 2001). Based on this weight of evidence, these three dimensions are adapted to measure the quality of the relationship between buyers and suppliers. Each of these dimensions are discussed in more detail below.

Trust is one of the most researched aspects of relationship quality and is frequently used as the central construct to assess the quality of buyer-supplier relationships (Johnston et al., 2004; Poppo et al., 2016). It is recognized as an essential factor that decreases uncertainty in exchange relationships (Geyskens et al., 1996; Morgan and Hunt, 1994). Blau (1964: 940) described trust as interpersonal, and firm-specific trust that is '...the belief that a party's word or promise is reliable, and a party will fulfil his/her obligations in an exchange relationship'. This incorporates the dimensions relating to credibility, honesty and competence, as well as benevolence or goodwill (Mishra, 1996; Nahapiet and Ghoshal, 1998; Rubin et al., 2017; Wu et al., 2014). Credibility and competence include the belief that the other party can perform the required tasks effectively and efficiently, whereas benevolence, goodwill and honesty mean they can trust their partner's intentions and motivations (Ganesan, 1994). Benevolence also implies the belief that each partner will act

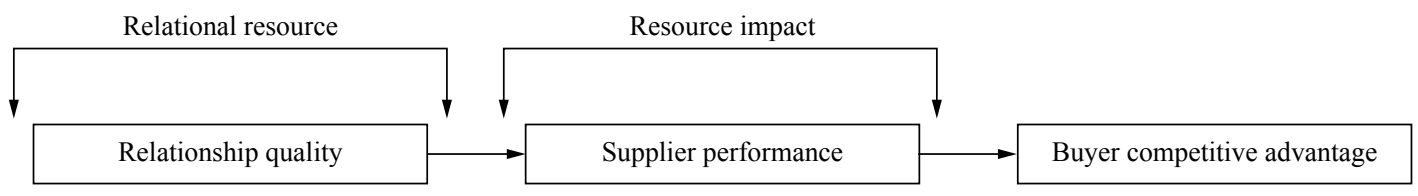

Figure 1. Theoretical framework. 
in the best interest of the other party. Based on these aspects of trust, the scale items for trust were adapted from those used by Anderson and Weitz (1992); Kumar et al. (1995b); Sako and Helper (1998); Tsai and Ghoshal (1998). Most recent studies use these seminal works as the basis of their scale development or use very similar scale items (Anderson et al., 2017; Doney and Cannon, 1997; Jain et al., 2013). In this case, these items were selected to cover the three dimensions of trust that included honesty, benevolence and goodwill, as well as competence (Supplementary Table S1).

Similar to trust, commitment is consistently understood to be an essential indicator of relationship quality and reflects the positive value of the relationship (Geyskens et al., 1998). Geyskens et al. (1999: 225) define commitment as a '...desire to continue the relationship in the future and a willingness to make shortterm sacrifices to maintain the relationship'. It is considered a measure of the desire for the relationship to continue and the willingness to make an effort on the other party's behalf. This means more than just a short-term evaluation of benefits and costs and reflects a willingness to invest financial, physical or relational resources to achieve long-term benefits (Geyskens et al., 1998; Morgan and Hunt, 1994; Wilson, 1995). Based on these definitions the scale items for commitment (Supplementary Table S2) were adapted from those used by Kumar et al. (1995a); Sako and Helper (1998); Tsai and Ghoshal (1998); Villena et al. (2011) (Supplementary Table S2).

Satisfaction is the third dimension of relationship quality used in this research. It is an important concept within exchange relationships and is a central tenant of relationship marketing, as well as channel and organizational research. Dwyer and Oh (1987) draw on the conceptualization of Ruekert and Churchill $\operatorname{Jr}$ (1984: 227) who define satisfaction as the overall assessment of the characteristics of the relationship, which are '...rewarding, profitable, instrumental and satisfying or frustrating, problematic, inhibiting, or unsatisfying'. It is multi-dimensional and incorporates economic and non-economic psychological aspects including social interaction and financial performance as well as features of the service and assistance provided by the partner (Gassenheimer and Ramsey, 1994; Geyskens et al., 1999; Homburg and Rudolph, 2001; Ruekert and Churchill Jr, 1984). The scale items for satisfaction were based on three dimensions of satisfaction that include satisfaction with price, support and communication (Supplementary Table S3). Using these three dimensions, the scale items were adapted from Anderson and Weitz (1992); Kumar et al. (1995a); Anderson and Narus (1984); Micheels and Gow (2011) and Nooteboom (2000).

This conceptualization of relationship quality as a measure of relationship resources was based on established definitions and validated scales, however, the actual measures were adapted for the measurement of these in the context procurement relationships in food supply chains.

\subsection{Supplier performance - resource impact}

Supplier performance is identified as the factor that provides the competitive outcome (resource impact) of relationship quality, leading to competitive advantage. The concept of supplier performance emerged from the literature on supplier development (Dorsch et al., 1998), describing the efforts of manufacturers to improve the performance of their suppliers. Supplier development is defined as any effort of a buying firm to increase the performance and or capabilities of their suppliers to meet the buying firm's supply needs (Wilson, 1995). Within this literature, relationship quality has emerged as an important antecedent for improving supplier performance (Hastings et al., 2016; Kannan and Tan, 2006; Kim et al., 2017; Lascelles and Dale, 1989). This study focuses on the quality of buyers' relationships with suppliers and how this can improve the performance of the supplier, enabling them to meet the needs of the buying firm.

The scales for supplier performance were determined from the buyers' perspective. This is consistent with the supplier development literature and refers to suppliers' improvements in communication, product quality and reliability that benefits the buying firm (Laaksonen et al., 2009). The research methodology specifically defined measures from the buyers' perspective. This was because the purpose of the research was to determine the supplier performance attributes that would improve the buyers' performance and therefore their competitive 
advantage. Furthermore, a key part of the research involved measuring the suppliers' perception of their performance; these performance measures were self-rated by the suppliers. There is good evidence that self-rating of performance is an accurate method to evaluate performance (Farh et al., 1988; Lindeman et al., 1995). Research has shown that though the absolute values may differ, the causal relationships are the same (Whipple et al., 2015). As supplier performance is highly contextual, the supplier performance items of communication, quality and loyalty were refined from the literature and interviews with the buyers in the sample. Each of these are now discussed in further detail.

The first of the supplier performance outcomes is communication and information sharing, which are important aspects of cooperative behavior and supplier performance. Anderson and Narus (1990: 44) define communication as, '...the formal as well as informal sharing of meaningful and timely information between firms. Effective supplier communication (as well as buyer communication) is an essential coordinating activity and is critical to overall supply chain performance. Information from suppliers enables firms to respond to customers' needs, reduce inventory costs and improve competitive advantage (Stank et al., 1999). In food supply chains, production volume, timing and quality, can be highly variable and affected by environmental factors as well as management decisions. Product quality also involves significant credence attributes that require a sharing of information throughout the supply chain in order to communicate these attributes to consumers (Agrawal and Kamakura, 1999; Lees and Saunders, 2015). An effective flow of product information from suppliers can benefit buyers through reduced variation, sorting costs and a greater ability to meet customer requirements (Micheels and Gow, 2011). From these considerations, the supplier communication scale items (Supplementary Table S4) were identified and adapted from those used by Anderson and Narus (1990).

Loyalty is a measure of the supplier's ongoing willingness to supply the buyer. Loyalty goes beyond calculative commitment and means that a supplier will continue to support a buyer even when it may not be economically rational to do so (Liu et al., 2010). Loyalty is defined as a state of attachment that is experienced as an allegiance or faithfulness (Gilliland and Bello, 2002; Liu et al., 2010). If a supplier has a strong sense of loyalty towards a buyer, then the supplier may sacrifice short-term benefits to achieve long-term objectives (Gilliland and Bello, 2002). A loyal supplier will try to resolve conflict in the relationship rather than exiting. Therefore, a fundamental component of loyalty is the forsaking of alternatives and becoming less sensitive to price, at least in the short term. The scale items for loyalty (Supplementary Table S5) were adapted from Liu et al. (2010) and Bensemann et al. (2011).

Meeting product quality specifications reduces sorting costs and helps the buyer to meet their customers' requirements. Having suppliers with the ability to achieve quality standards is, therefore, a critical factor in providing a competitive advantage and a superior performance for the buyer (Kroll et al., 1999; Reed et al., 2000). Product quality is a highly context-specific with quality differing depending on the type of product and production system. In this research, the product quality scales define quality from an animal product perspective with the scale items developed to incorporate delivery reliability in terms of the numbers of animals as well as their quality (Supplementary Table S6).

\subsection{Theoretical model}

The theoretical model (Figure 2) used is developed from the theoretical framework (Figure 1). All relationships between variables are hypothesized to be positive $(+)$.

This model leads to the following hypotheses to be tested. The first hypothesis $(\mathrm{H} 1 \mathrm{a}-\mathrm{c})$ proposes that relationship quality is a higher order construct with sub-dimensions that include, trust, satisfaction and commitment (Crosby et al., 1990; Dwyer and Oh, 1987; Kumar et al., 1998; Lages et al., 2005; Ulaga and Eggert, 2006). Measuring the overall quality of relationships between buyers and suppliers is complex. Being a multi-dimensional construct suppliers may evaluate the overall quality of their relationship with buyers based on more recent experiences and specific dimensions of the relationship that is biased by 


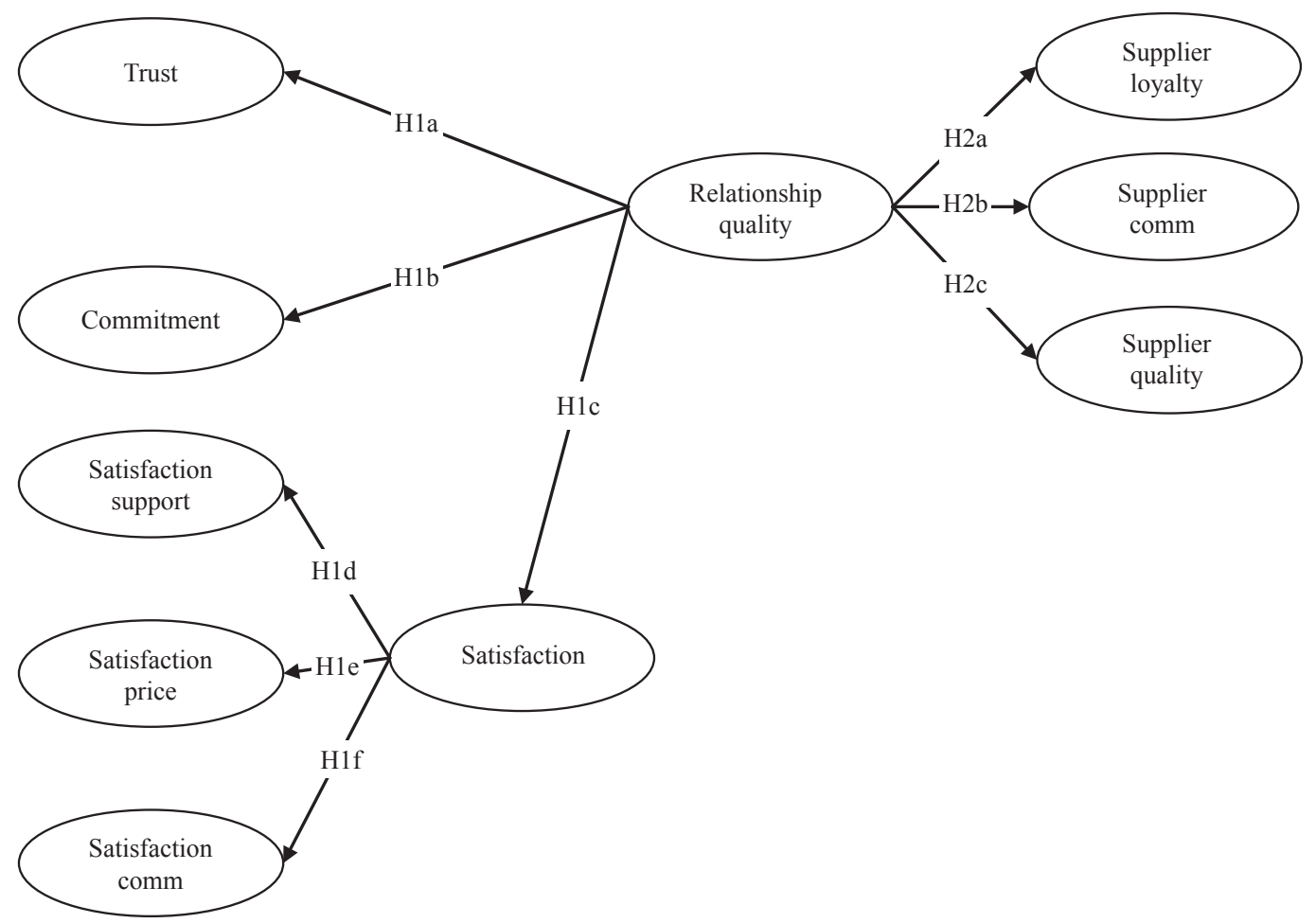

Figure 2. Theoretical model.

information more easily accessed by memory (Kahneman, 2011). Therefore, it was necessary to measure the individual sub-dimensions (trust, commitment, satisfaction) that are more specific and therefore more accurately evaluated by suppliers. Quality relationships require a high level of trust between buyers and suppliers meaning suppliers are confident the buyer will act in their best interests and have the ability to deliver on their promises. Commitment is also a sign of the quality of the relationship as it means that they desire a continuing relationship. Finally, quality relationships require that suppliers are satisfied with both the economic and psychological aspects. Hence,

H1: Relationship quality is positively related to:
a. trust
b. commitment
c. satisfaction

The second set of hypotheses follow the first (H1 d-f) and tests the economic and non-economic structure of satisfaction. The economic evaluation includes an assessment of the financial rewards. The non-economic aspects include social interaction, communication as well as features of the service and assistance provided by the partner (Geyskens et al., 1999). These hypotheses test the theoretical model that proposes that satisfaction as made up of sub-dimensions that include satisfaction with price, communication and the performance of the buyer organization. Thus,

H1: Satisfaction is positively related to the sub-dimensions of:

d. satisfaction with the organization (buyer)

e. satisfaction with price

f. satisfaction with buyer's communication

Furthermore, there is considerable literature on the effect of relationship quality as a way to improve supplier performance (Fynes et al., 2005; Joshi et al., 2018). When buyers enhance the quality of their relationship with 
suppliers, then suppliers are more willing to make efforts to meet the buyer's requirements (Athanasopoulou, 2009). Where there are closer relationships with suppliers, then they are able to understand the buying firm's requirements and can adjust their production systems to better meet these. This is particularly relevant for food suppliers who were delivering products that meet consumer requirements may involve significant production changes which take time to implement. Improving the quality of buyer-supplier relationships means suppliers will make greater efforts to meet the buyer's product quality specifications. For example, Han et al. (1993) identify that improved relationships with suppliers leads to improved reliability of supply and delivery schedules.

Therefore, relationship quality is tested with supplier (product) quality, supplier loyalty and supplier communication as three sub-dimensions of supplier performance. This is leads to Hypotheses $\mathrm{H} 2 \mathrm{a}-\mathrm{c}$, as follows:

H2a: Improving relationship quality will have a positive impact on supplier product quality.

Next, improving the quality of buyer-supplier relationships means suppliers will be more loyal to their buyer and less likely to switch to an alternative. Building close relationships are costly and takes time to develop meaning suppliers are less likely to seek other buyers, hence;

H2b: Improving relationship quality will have a positive impact on supplier loyalty.

Finally, improving the quality of buyer-supplier relationships will increase a supplier's communication and information sharing with their buyer. For example (Dyer and Chu, 2003; Reagans and McEvily, 2003) find a strong relationship between the trust, communication and sharing of information dimensions. Sharing of information with buyers can be risky as it provides the opportunity for the buyer to take advantage of this information and act opportunistically. Suppliers will only share important information if they have a close working relationship that mitigates the risk of opportunistic behavior, hence:

H2c: Improving relationship quality will have a positive impact on supplier communication.

\section{Methods}

This research used quantitative research methods. The quantitative research was able to measure the relationships and test the hypotheses between the constructs by providing tests for statistical significance and model fit. The development of the survey instrument followed a process based on recommendations of Churchill (1979).

Firstly, a review of the literature identified how the constructs had been measured in the past. Following this, discussions with suppliers and purchasing company staff helped select and develop the scale items. These were used in a pre-test survey which was sent to the food company personnel and administered in person to ten farmer suppliers selected by the food companies. This tested for structure, readability, ambiguity and overall completeness. Changes were made to the survey to address any of these issues identified. Structural equation modelling was chosen for this research due to its ability to analyze a large number of interrelated relationships in a single analysis. It also enables the analysis of relationships between latent constructs.

\subsection{Data collection}

The sampling frame for the quantitative data was the New Zealand AsureQuality registered farmers database. This database contained the names and contact details for 5,944 farmers with farms over 30 ha. The sample was stratified according to location, size and farm type using Statistics New Zealand data to ensure representativeness. The first mail out had a $12 \%$ response rate and the second $11 \%$. This resulted in a $20 \%$ response rate after the two mailings. The responses were tested for representativeness, and non-response bias 
using paired $t$-tests, confirming the data was representative of the sample populations and that there was no significant difference in the results between the mailings. The response rate was considered sufficient for meaningful analysis (Hair et al., 2010).

\section{Analysis and results}

The descriptive analysis identified differences between suppliers on a range of factors (Table 1). Sheep farms were significantly larger than beef and venison farms with family farms being the most common type of farm ownership (88\%) showing most of the respondents were individual farmers. There was a spread in the length of time farmers had been supplying their processor ranging between $0-4$ years $(19 \%)$ to farmers who had been supplying for more than 20 years (31\%), see Table 1 . Another $30 \%$ had been supplying their processor for more than 30 years indicating the existence of long-term supply relationships. While approximately $20 \%$ of farmers sell at least some stock on contract, none committed all their stock to a contract supply arrangement. Of the $20 \%$ who sold some stock involving a contract, on average $49 \%$ of their total stock was on contract. From this, it can be estimated that approximately $20 \%$ of all stock were sold involving a contract showing contract supply was not the most common supply relationship. A significant proportion of suppliers owned shares in cooperative processors (Supplementary Table S12). 40\% had owned shares in their cooperative for more than 10 years (Supplementary Table S13) indicating they had a long term investment in the cooperative.

Following the descriptive analysis, the data was analyzed using exploratory factor analysis enabling the latent variables to be identified by evaluating the common variance among the scale measures (Table 2). Measurement items were retained that possessed an Eigenvalue of greater than one, and a factor loading of greater than 0.45. Measurement items that cross-loaded onto multiple factors were deleted. This resulted in eight latent variables emerging with a total variance explained of 70\% (Supplementary Table S7). Scale reliability and internal consistency were measured using Cronbach's Alpha, and in the confirmatory factor analysis, by the critical ratio (CR). Cronbach's Alpha scores ranged from 0.66 for supplier quality to 0.94 for trust (Table 2). There are a variety of acceptable alpha values reported in the literature, ranging from

Table 1. Descriptive analysis of farm data.

\begin{tabular}{lc}
\hline & Mean of farm size (ha) \\
\hline Farm type & 276 \\
Beef & 991 \\
Sheep & 284 \\
Deer & \\
Ownership type & $3 \%$ \\
$\quad$ Corporate farm & $88 \%$ \\
Family farm & $1 \%$ \\
Maori trust/corporation ${ }^{1}$ & $8 \%$ \\
Other & $19 \%$ \\
Years supplying stock the processor & $31 \%$ \\
$\quad 0-4$ years & $20 \%$ \\
5-10 years & $30 \%$ \\
10-20 years & \\
20+ years & $39 \%$ \\
Supplied stock on contract & $49 \%$ \\
$\quad \%$ of farmers who supply stock on contract & \\
$\quad \%$ of stock supplied on contract ${ }^{2}$ (mean) & \\
${ }^{1}$ A Maori trust or corporation is an organisation that manages land in common ownership by Maori Iwi (tribes). \\
${ }^{2}$ Average \% of stock supplied on contract by those suppliers who commit to a contract.
\end{tabular}


0.70 to 0.95 (Tavakol and Dennick, 2011). Values as low as 0.60 are considered acceptable in exploratory research (Hair et al., 2010). Based on these considerations the values were deemed acceptable for the purpose of this research.

Table 2. Exploratory factor analysis.

\begin{tabular}{|c|c|c|c|c|}
\hline Item & Factor loading & $\begin{array}{l}\text { Cronbach's } \\
\text { alpha }\end{array}$ & Critical ratio & $\begin{array}{l}\text { Variance } \\
\text { extracted }\end{array}$ \\
\hline Trust & & 0.94 & 0.94 & $16.4 \%$ \\
\hline Trust2_Welfare & 0.79 & & & \\
\hline Trust5_Advantage & 0.78 & & & \\
\hline Trust4_Fair & 0.77 & & & \\
\hline Trust1_Explain (Truth) & 0.77 & & & \\
\hline Trust6_Returns & 0.71 & & & \\
\hline Trust3_Agree & 0.70 & & & \\
\hline Trust8_Honest & 0.70 & & & \\
\hline Trust9_Inform & 0.65 & & & \\
\hline Commitment & & 0.83 & 0.88 & $9.4 \%$ \\
\hline Commitment4_Invest & 0.71 & & & \\
\hline Commitment2_Resources & 0.65 & & & \\
\hline Commitment1_LongTerm & 0.58 & & & \\
\hline Commitment3_Proud & 0.56 & & & \\
\hline Satisfaction price & & 0.80 & 0.80 & $7.6 \%$ \\
\hline Satisfaction9_Expect & 0.75 & & & \\
\hline Satisfaction4_Price & 0.73 & & & \\
\hline Satisfaction10_PriceStock & 0.72 & & & \\
\hline Satisfaction5_Schedule & 0.66 & & & \\
\hline Satisfaction organisation & & 0.91 & 0.90 & $12.0 \%$ \\
\hline Satisfaction1_NetReturn & 0.80 & & & \\
\hline BuyAbility3_Premium & 0.79 & & & \\
\hline BuyAbility1_Market & 0.76 & & & \\
\hline BuyAbility2_SupplyChain & 0.75 & & & \\
\hline Satisfaction 3 _Policies & 0.67 & & & \\
\hline Satisfaction2_Support & 0.62 & & & \\
\hline Satisfaction communication & & 0.88 & 0.88 & $7.5 \%$ \\
\hline Satisfaction7_CommTime & 0.83 & & & \\
\hline Satisfaction8_CommQual & 0.81 & & & \\
\hline Satisfaction6_Support & 0.72 & & & \\
\hline Supplier communication & & 0.83 & 0.84 & $4.9 \%$ \\
\hline SupplierComm2_Plans & 0.87 & & & \\
\hline SupplierComm1_Delivery & 0.81 & & & \\
\hline Loyalty & & 0.78 & 0.77 & $7.6 \%$ \\
\hline Loyalty_L3_PriceOnly & 0.76 & & & \\
\hline Loyalty_L4_SpotMarket & 0.70 & & & \\
\hline Loyalty_L1_Options & 0.70 & & & \\
\hline Loyalty_L5_SupplyOne & 0.66 & & & \\
\hline Loyalty_L2_PriceCompetition & 0.58 & & & \\
\hline Supplier quality & & 0.66 & 0.66 & $4.2 \%$ \\
\hline Quality2_Specs & 0.82 & & & \\
\hline Quality1_Reliability & 0.80 & & & \\
\hline
\end{tabular}


Figure 3 describes the measurement model used to test the validity of the constructs to be used in the structural equation model. This uses the results of the exploratory factor analysis; however, the measurement model specifies the scale items that load onto each latent variable.

IBM Amos 22.0 software (IBM, Armonk, NY, USA) was used to evaluate construct validity and estimate the model fit of the measurement model. The results of the confirmatory factor analysis model show a good model fit on all the fit criteria (Table 3). All the composite reliability (CR) scores were greater than 0.70 , other than the CR for supplier quality.

The results of the confirmatory factor analysis were used to identify any concerns regarding the validity of the measures. All items met the requirements for discriminant validity. Convergent validity was tested with a cut-off for the AVE to be greater than 0.50 . Both supplier loyalty and supplier quality did not meet this standard cut off criteria. However, as the AVE for these variables were only slightly below this cut off they were considered acceptable for testing to proceed (Table 4).

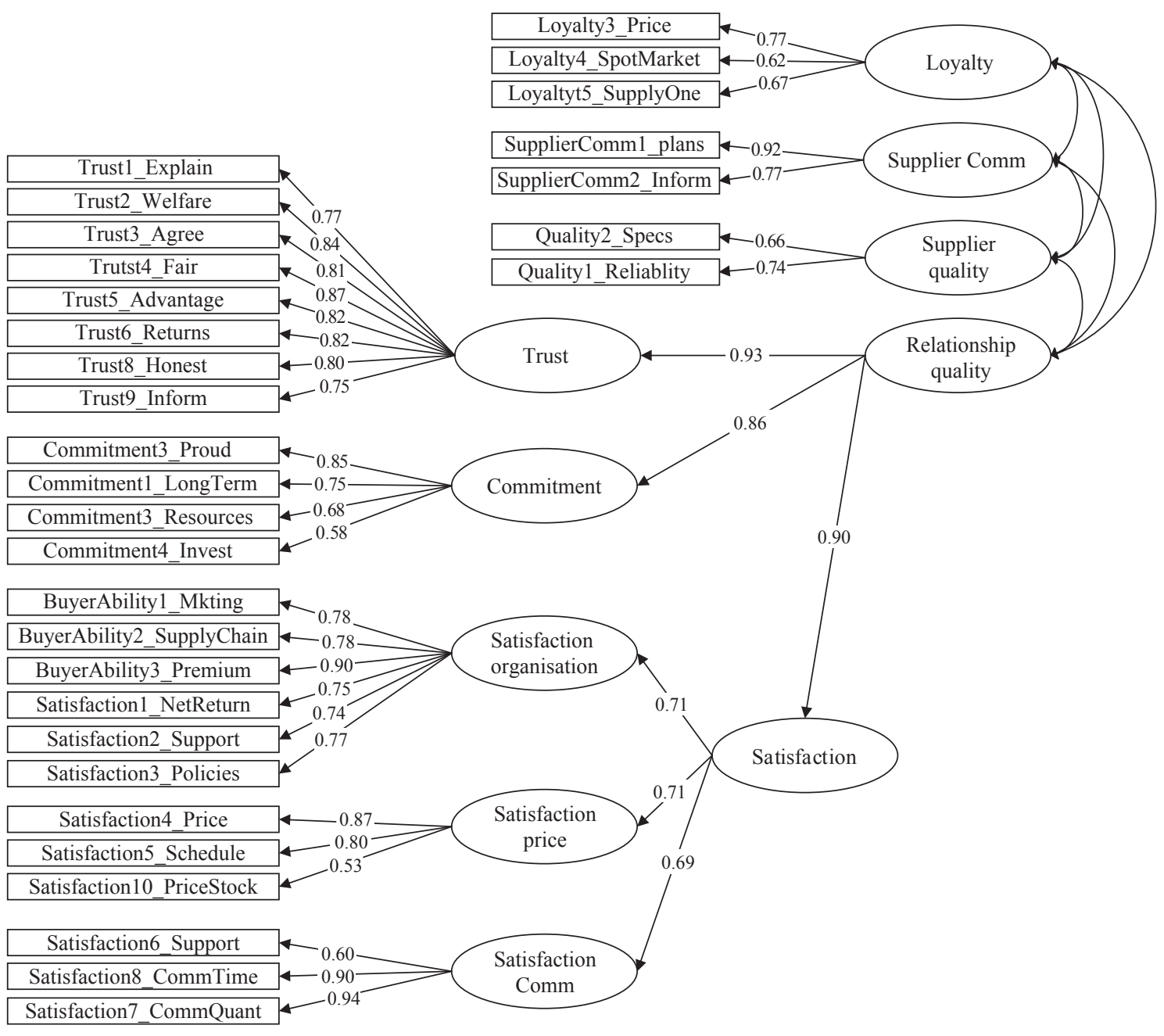

Figure 3. Measurement model (confirmatory factor analysis). 
Table 3. Model fit criteria for measurement and structural models. ${ }^{1}$

\begin{tabular}{lll}
\hline Measure & Measurement model & Structural model \\
\hline Chi-square/df (cmin/df) & 2.7 & 3.0 \\
CFI & 0.96 & 0.96 \\
GFI & 0.92 & 0.93 \\
AGFI & 0.90 & 0.91 \\
RMSEA & 0.042 & 0.05 \\
PCLOSE & 0.99 & 0.96 \\
\hline${ }^{1}$ AGFI = adjusted goodness-of-fit statistic; CFI = comparative fit index; GFI = goodness-of-fit statistic; PCLOSE = p of close fit; \\
RMSEA = root mean square error of approximation.
\end{tabular}

Table 4. Correlations between constructs. ${ }^{1}$

\begin{tabular}{llllllll}
\hline & CR & AVE & MSV & $\mathbf{1}$ & $\mathbf{2}$ & $\mathbf{3}$ & $\mathbf{4}$ \\
\hline Supplier communication & 0.84 & 0.72 & 0.19 & - & & & \\
Supplier loyalty & 0.73 & 0.48 & 0.27 & 0.44 & - & & \\
Supplier quality & 0.66 & 0.49 & 0.13 & 0.36 & 0.19 & - & \\
Relationship quality & 0.92 & 0.79 & 0.27 & 0.37 & 0.52 & 0.21 & - \\
\hline
\end{tabular}

${ }^{1} \mathrm{CR}=$ composite reliability; AVE = average variance explained; $\mathrm{MSV}=$ maximum shared variance.

Figure 4 describes the structural model including the measurement items developed from the Principle Component Analysis and the Measurement Model. There were significant paths from trust $(0.90 * * *)$, commitment $\left(0.86^{* * *}\right)$ and satisfaction $\left(0.90^{* * *}\right)$ to relationship quality confirming the hypotheses H1a-c. The model also showed significant paths from 'satisfaction with price' $(0.72 * * *)$, communication $(0.69 * * *)$ and the 'satisfaction with the buyer's organization' $(0.70 * * *)$ confirming the hypotheses H1d-f. These results indicated that the proposed model of the structure of relationship quality was valid. Finally, the structural model showed significant paths from relationship quality to all three of the supplier performance variables, confirming the hypotheses H2a-c. The overall fit statistics shown in Table 3 exceeded the required values that indicate a good model fit (Hu and Bentler, 1999). The path from relationship quality to supplier loyalty had the greatest standardised regression value $(0.53 * * *)$ followed by supplier communication $(0.38 * * *)$. Though there was a significant effect on supplier quality, this was lower than the values for the other two variables $(0.23 * * *)$.

The $\mathrm{R}^{2}$ values reveal differences in the explanatory power of relationship quality on the dependent variables. For supplier loyalty and supplier communication, relationship quality explains $18-28 \%$ of the variance respectively (Table 5 and Figure 5). There is also evidence from the regression weights that improving relationship quality will improve supplier communication and supplier loyalty. The results for supplier quality are less conclusive. While there is a significant $(P<0.001)$ relationship with the independent variable, the low $\mathrm{R}^{2}$ value indicates that there are factors other than relationship quality that affect supplier quality. These could include supplier specific factors such as supplier ability, customer focus as well as farm characteristics. 


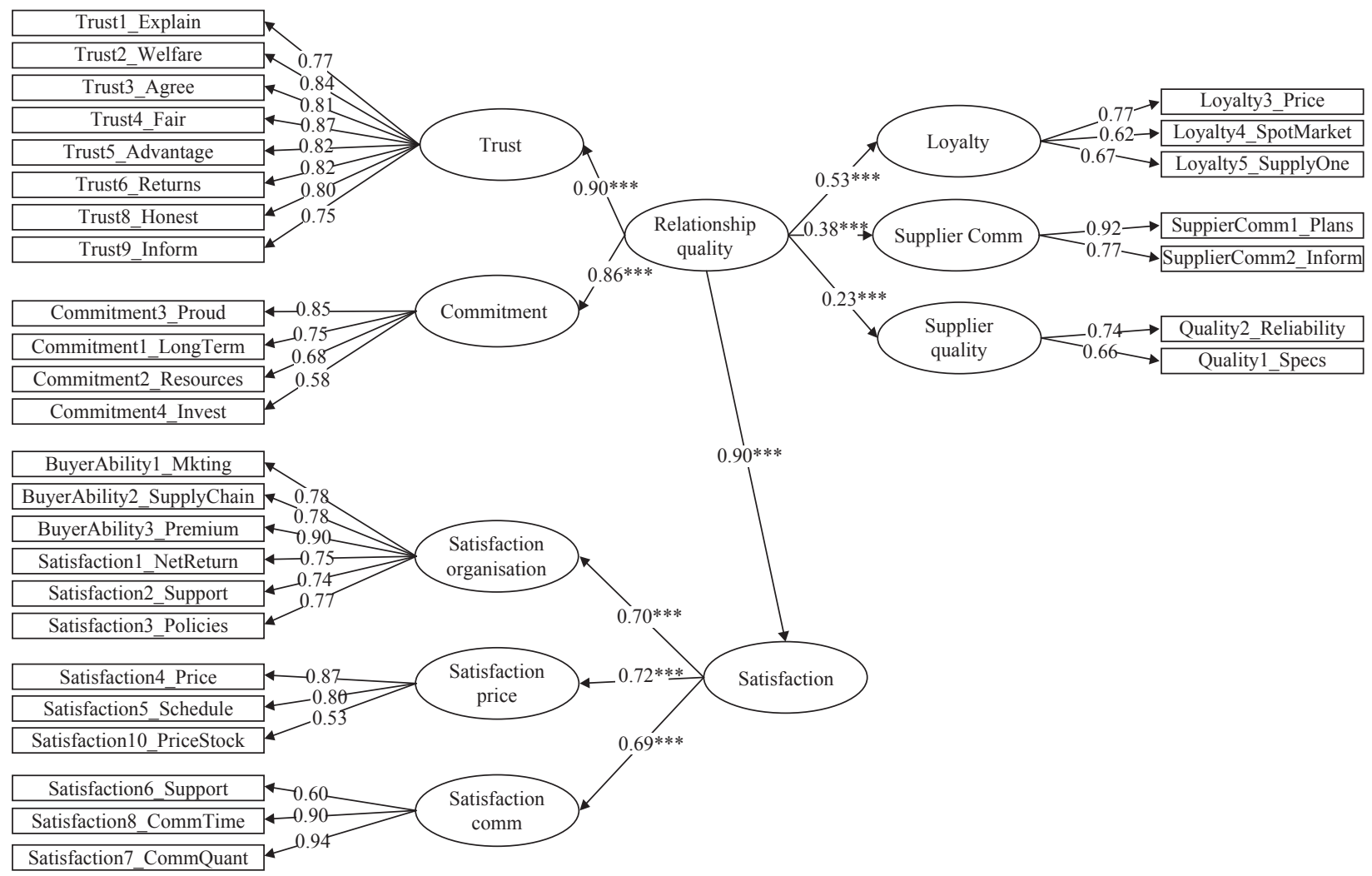

Figure 4. Structural model for constructs and measures.

Table 5. Standardized effects and $R^{2}$ values for relationships between relationship quality and supplier performance. ${ }^{1}$

\begin{tabular}{|c|c|c|c|c|c|c|c|c|}
\hline Path to: & Path from: & Estimate & $\begin{array}{l}\text { Standardized } \\
\text { estimate }\end{array}$ & SE & $\mathbf{C R}$ & $R^{2}$ & Hypothesis & Supported \\
\hline Supplier loyalty & relationship quality & $0.58 * * *$ & $0.53^{* * *}$ & 0.05 & 12.6 & 0.28 & $\mathrm{H} 2 \mathrm{a}$ & yes \\
\hline Supplier quality & relationship quality & $0.16^{* * *}$ & $0.23^{* * *}$ & 0.03 & 5.2 & 0.04 & $\mathrm{H} 2 \mathrm{~b}$ & yes \\
\hline $\begin{array}{l}\text { Supplier } \\
\text { communication }\end{array}$ & relationship quality & $0.58 * * *$ & $0.38^{* * *}$ & 0.04 & 11.2 & 0.18 & $\mathrm{H} 2 \mathrm{c}$ & yes \\
\hline
\end{tabular}

${ }^{1}$ Significance levels: $P<0.001 * * *, P<0.05 * *, P<0.10 *$. $\mathrm{CR}=$ critical ration $>0.7$; $\mathrm{SE}=$ standard error.

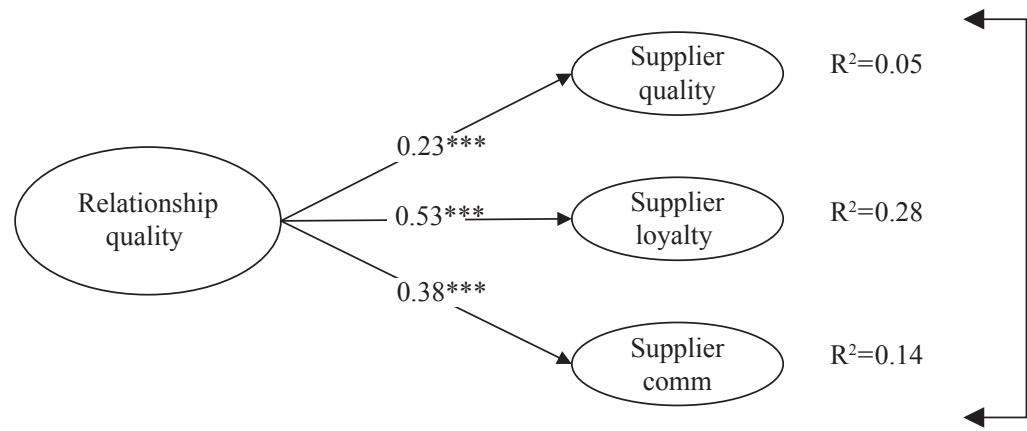

Supplier

performance

Figure 5. The effect of relationship quality on supplier performance. 


\section{Discussion and conclusions}

The results establish a validated model of relationship quality in the context of procurement relationships with suppliers in food supply chains. The model showed that constructs such as trust, commitment and satisfaction that have emerged from other industry contexts are also relevant in food supply chains. While many measures could be directly adapted to the food industry context others scale items for constructs such as product quality needed to be developed. This validated model provides a platform for further research on relationship quality in food supply chains. The results also support the positive link between relationship quality and supplier performance.

These results have relevance to purchasing practice as they provide an understanding of what factors can be manipulated to improve the quality of relationships with suppliers and how this might impact their performance. For example, the model shows that satisfaction with price is only one dimension of satisfaction. This means that increasing the amount paid to suppliers may not by itself improve overall supplier satisfaction but improving communication and performance of buyers organization are also important. Furthermore, building a quality relationship with suppliers requires a focus on the multiple dimensions of relationship quality. For example, building trust with suppliers will provide some improvement in relationship quality but there also needs to be an emphasis on commitment and satisfaction.

This research that shows the importance of relationship quality in procurement relationships with food suppliers is important as agricultural markets are often viewed as involving commodity trading through spot markets with a highly fragmented supplier base (Touboulic and Walker, 2015). This view implies the dominance of transactional relationships with suppliers which this research indicates is not always the case. The results indicate that relationship quality is important in food supply chains. Furthermore, they were also shown to be important when suppliers and consumers are separated over large geographic distances and when the majority of the product is exported as is the case with New Zealand agricultural products. In addition, the products in this research also were biological products that are highly perishable and consumer requirements incorporate important credence attributes. It also demonstrates that relationship quality becomes particularly important for suppliers who are individuals rather than organizations. Palmatier et al. (2006) note that relationships are more important when they are '...built with an individual person rather than a selling firm' (Palmatier et al., 2006: 136).

Supplier quality relates to both the quality and quantity of animals supplied and the timing of delivery. The results indicate that processors, who require higher quality animals delivered at specific times, do need to build stronger relationships with suppliers if these specifications are to be met. However, the results suggest there are other variables that are more important than relationship quality. Delivering quality animals may be a result of other factors such as a supplier's technical ability as well as farm resources and the particular climate and season. Delivering the required quality and numbers at specific times in a free range/grass-based system is difficult as the producer may have little control over the environment and availability of feed supply. Less flexible delivery schedules can directly affect a supplier's profitability by increasing costs and effort.

Relationship quality is therefore essential as suppliers need to trust they will be sufficiently rewarded for meeting the required quality and delivery specifications. This supports the findings of Kannan and Tan (2002) who report that it is easier to address supplier delivery problems if there is a good relationship between buyer and supplier. Furthermore, they state that while cost may be an important criterion for buyers, quality, delivery and service are also important.

The results further support the findings of Kannan and Tan (2002) and Lambert (2006) that relationships between buyers and sellers are an essential component of supply chain performance. Furthermore, the findings highlight that these relationships are also important in the context of food supply chains. This is consistent with the work of Grimm et al. (2014) and Van der Vorst and Beulens (2002) who assert that high-quality relationships are required to manage the greater uncertainty and complexity that arise in the production, 
distribution and consumption of food products. Furthermore, Ziggers and Trienekens, (1999) describe the particular importance of relationships and coordination in meat supply chains where there is a direct link between the intrinsic attributes of the primary product and the final product.

This uncertainty and complexity is compounded in food supply chains when moving from producing undifferentiated commodity food products to products with diverse value-added characteristics that target specific consumer requirements (Ziggers and Trienekens, 1999). Supplier loyalty and information sharing are necessary to enable differentiated products with specific market requirements to be produced and delivered to consumers. This is especially important where consumers require credence attributes that are to be communicated along with physical product characteristics (Wognum et al., 2011).

The RBV and RV theoretical perspectives are further confirmed by the results showing relational resources enable firms to access valuable resources from their exchange partners (Dyer and Singh, 1998). In the New Zealand setting, animal production is grass-based, production is spread over a wide geographical area, and there is a significant amount of tacit knowledge involved in farm management. This requires a large number of individual farmers with considerable expertise and experience to produce the quality and quantity of product required. Owning the farms physical and human resources is not feasible for buyers due to the substantial capital requirements (Ziggers and Trienekens, 1999) and the tacit knowledge and expertise needed by farm managers (Schmidt et al., 2012). Securing long-term access to these valuable resources is vital for a buyer's competitive advantage. Furthermore, building long-term quality relationships with suppliers takes time and considerable investment. However, this also means that these relationships become valuable, rare and difficult to copy resources for the buying firm which support a sustainable competitive advantage through improved supplier performance.

From a firm managerial perspective, the research indicates that developing quality supplier relationships characterized by high levels of trust, commitment and satisfaction is crucial to improved performance in food supply chains. Strong supplier relationships enable food supply chains to move away from commodity products and spot market transactions to compete with higher value differentiated products. This requires suppliers to be loyal and freely share information with their buyer. Improved communication also enables buyers to enhance their competitiveness by efficiently responding to consumer needs and reduce costs (Stank et al., 1999). Information sharing also enables transparency in the supply chain and the ability to communicate credence attributes to consumers. The research emphasizes that buyers need to invest time and effort in developing relational resources. Given the large number of geographically dispersed individual suppliers in the New Zealand meat industry, this often requires additional procurement staff that have the relational skills necessary to develop these relationships.

It is also important for buyers to know how they can influence the quality of the product. Given the low variance explained for supplier quality, further research is needed in an attempt to identify additional latent factors that also influence supplier quality. These other factors may possibly include supplier specific factors not readily influenced by supplier development programs. Examples include supplier ability and personality which impact on supplier quality though there may be little a buyer can do to modify these factors. This places greater importance on buyers having effective supplier selection criteria. The positive association between relationship quality and supplier performance in the food context has been clearly validated. In particular, it provides evidence for the influence of relationship quality on supplier communication and supplier loyalty. The results confirm the importance of relationship quality that has been established in the manufacturing and service industries.

Though the research makes a valuable theoretical and managerial contribution, there are several limitations that provide areas for future research. Firstly, besides communication, loyalty and quality, there may be a number of other factors that contribute to supplier performance. More work needs to be done to define the supplier quality construct and to identify factors that influence this variable. The quality characteristics of food products are highly variable between specific food products. For example, ethical concerns over animal 
welfare are important to consumers of animal products but not for horticultural products. Further research could define and compare supplier relationships and performance for different food industries and identify how these factors vary with different biological products and as well as identify specific farm or farmer characteristics that may influence relationship quality.

The impact of the current global food system on human health and the environment makes this research on relationships between actors in food supply chain of great importance (Poore and Nemecek, 2018; Willett et al., 2019). Developing a basis for measuring the quality of relationships in food supply chains and understanding how this impacts supplier behavior is an essential step to improving the performance of the modern food system.

\section{Supplementary material}

Supplementary material can be found online at https://doi.org/10.22434/IFAMR2019.0178

Table S1. Trust scale items.

Table S2. Commitment scale items.

Table S3. Satisfaction scale items.

Table S4. Supplier communication scale items.

Table S5. Supplier loyalty scale items.

Table S6. Supplier quality scale items.

Table S7. Eigen values and \% of variance explained.

Table S8. Standardized regression weights.

Table S9. Sample characteristics: farm type.

Table S10. Sample characteristics: farm ownership.

Table S11. Sample characteristics: respondents' role in the farm business.

Table S12. Sample characteristics: ownership in processor.

Table S13. Sample characteristics: length of share ownership.

Table S14. Sample characteristics: length of time supplying current processor.

Table S15. Control variables: regression weights for control variables - ownership.

\section{References}

Agrawal, J. and W.A. Kamakura. 1999. Country of origin: a competitive advantage? International Journal of Research in Marketing 16(4): 255-267.

Anderson, E. and B. Weitz. 1992. The use of pledges to build and sustain commitment in distribution channels. Journal of Marketing Research 29(1): 18-34.

Anderson, J.C. and J.A. Narus. 1984. A model of the distributor's perspective of distributor-manufacturer working relationships. Journal of Marketing 48(4): 62-74.

Anderson, J.C. and J.A. Narus. 1990. A model of distributor firm and manufacturer firm working partnerships. The Journal of Marketing 54(1): 42-58.

Anderson, S.W., H.F. Chang, M.M. Cheng and Y.S. Phua. 2017. Getting to know you: trust formation in new interfirm relationships and the consequences for investments in management control and the collaboration. Contemporary Accounting Research 34(2): 940-965.

Ateş, M.A., F. Wynstra and E.M. van Raaij. 2015. An exploratory analysis of the relationship between purchase category strategies and supply base structure. Journal of Purchasing and Supply Management 21(3): 204-219.

Athanasopoulou, P. 2009. Relationship quality: a critical literature review and research agenda. European Journal of Marketing 43(5-6): 583-610.

Baker, A. and S.J. Smyth. 2012. Managing opportunism in value-added supply chains: lessons from organics. Journal of International Food \& Agribusiness Marketing 24(1): 22-46.

Barney, J. 1991. Firm resources and sustained competitive advantage. Journal of Management 17(1): 99-120. 
Barney, J.B. 2012. Purchasing, supply chain management and sustained competitive advantage: the relevance of resource-based theory. Journal of Supply Chain Management 48(2): 3-6.

Bensemann, J., N. Shadbolt and D. Conforte. 2011. Farmers'choice of marketing strategies: a study of New Zealand lamb producers. Paper presented at the International Food and Agribusiness Conference. June 10-14, 2011. Shanghai, China.

Beske, P., A. Land and S. Seuring. 2014. Sustainable supply chain management practices and dynamic capabilities in the food industry: a critical analysis of the literature. International Journal of Production Economics 152: 131-143.

Blau, P.M. 1964. Exchange and power in social life. John Wiley, New York, NY, USA.

Brooks, S., A. Leaver, M. Spence, C.T. Elliott and M. Dean. 2017. Pragmatic engagement in a low trust supply chain: beef farmers' perceptions of power, trust and agency. Competition \& Change 21(2): 114-131.

Cannon, J.P., P.M. Doney, M.R. Mullen and K.J. Petersen. 2010. Building long-term orientation in buyersupplier relationships: the moderating role of culture. Journal of Operations Management 28(6): 506-521.

Chen, Y.S., H.C. Su, and Y.K. Ro. 2017. The co-evolution of supplier relationship quality and product quality in the US auto industry: a cultural perspective. International Journal of Production Economics 184: 245-255.

Choi, T.Y. and Z. Wu. 2009. Taking the leap from dyads to triads: buyer-supplier relationships in supply networks. Journal of Purchasing and Supply Management 15(4): 263-266.

Churchill, G.A. 1979. A paradigm for developing better measures of marketing constructs. Journal of Marketing Research 16(1): 64-73.

Clemens, R.L. and B.A. Babcock. 2004. Country of origin as a brand: the case of New Zealand lamb. CARD Reports and Working Papers, Iowa State University, Ames, IA, USA. Available at: http://lib. dr.iastate.edu/matric_briefingpapers/5

Conner, K.R. 1991. A historical comparison of resource-based theory and five schools of thought within industrial organization economics: do we have a new theory of the firm? Journal of Management 17(1): 121-154.

Crosby, L.A., K.R. Evans and D. Cowles. 1990. Relationship quality in services selling: an interpersonal influence perspective. The Journal of Marketing 54(3): 68-81.

Doney, P.M. and J.P. Cannon. 1997. An examination of the nature of trust in buyer-seller relationships. Journal of Marketing 61(2): 35-51.

Dorsch, M.J., S.R. Swanson and S.W. Kelley. 1998. The role of relationship quality in the stratification of vendors as perceived by customers. Journal of the Academy of Marketing Science 26(2): 128-142.

Duffy, R. and A. Fearne. 2004. The impact of supply chain partnerships on supplier performance. The International Journal of Logistics Management 15(1): 57-72.

Dwyer, F.R. and S. Oh. 1987. Output sector munificence effects on the internal political economy of marketing channels. Journal of Marketing Research 24(4): 347-358.

Dwyer, F.R., P.H. Schurr and S. Oh. 1987. Developing buyer-seller relationships. The Journal of Marketing 51(2): 11-27.

Dyer, J.H. and H. Singh. 1998. The relational view: cooperative strategy and sources of interorganizational competitive advantage. The Academy of Management Review 23(4): 660-679.

Dyer, J.H. and W. Chu. 2003. The role of trustworthiness in reducing transaction costs and improving performance: empirical evidence from the United States, Japan and Korea. Organization Science 14(1): 57-68.

Farh, J.-L., J.D. Werbel and A.G. Bedeian. 1988. An empirical investigation of self-appraisal-based performance evaluation. Personnel Psychology 41(1): 141-156.

Federal Reserve. 2019. Summary of commentary on current economic conditions. Federal Reserve District, Chicago, IL, USA.

Folkerts, H. and H. Koehorst. 1998. Challenges in international food supply chains: vertical co-ordination in the European agribusiness and food industries. British Food Journal 100(8): 385-388.

Fynes, B., C. Voss and S. de Búrca. 2005. The impact of supply chain relationship quality on quality performance. International Journal of Production Economics 96(3): 339-354. 
Fynes, B., S. de Búrca and J. Mangan. 2008. The effect of relationship characteristics on relationship quality and performance. International Journal of Production Economics 111(1): 56-69. https://doi. org/10.1016/j.ijpe.2006.11.019

Gadde, L.E. and I. Snehota. 2000. Making the most of supplier relationships. Industrial Marketing Management 29(4): 305-316.

Ganesan, S. 1994. Determinants of long-term orientation in buyer-seller relationships. Journal of Marketing 58(2): 1-19.

Gassenheimer, J.B. and R. Ramsey. 1994. The impact of dependence on dealer satisfaction: a comparison of reseller-supplier relationships. Journal of Retailing 70(3): 253-266.

Gellynck, X., B. Kühne and R.D. Weaver. 2011. Relationship quality and innovation capacity of chains: the case of the traditional food sector in the EU. International Journal of Food System Dynamics 2(1): 1-22.

Geyskens, I., J.B. Steenkamp and N. Kumar. 1998. Generalizations about trust in marketing channel relationships using meta-analysis. International Journal of Research in Marketing 15(3): 223-248.

Geyskens, I., J.B. Steenkamp and N. Kumar. 1999. A meta-analysis of satisfaction in marketing channel relationships. Journal of Marketing Research 36(2): 223-238.

Geyskens, I., J.B. Steenkamp, L.K. Scheer and N. Kumar. 1996. The effects of trust and interdependence on relationship commitment: a trans-Atlantic study. International Journal of Research in Marketing 13(4): 303-317.

Gilliland, D.I. and D.C. Bello. 2002. Two sides to attitudinal commitment: the effect of calculative and loyalty commitment on enforcement mechanisms in distribution channels. Journal of the Academy of Marketing Science 30(1): 24-43.

Gorton, M., R. Angell, L. Dries, V. Urutyan, E. Jackson and J. White. 2015. Power, buyer trustworthiness and supplier performance: evidence from the Armenian dairy sector. Industrial Marketing Management 50: 69-77.

Govindan, K. 2018. Sustainable consumption and production in the food supply chain: a conceptual framework. International Journal of Production Economics 195: 419-431.

Grimm, J.H., J.S. Hofstetter and J. Sarkis. 2014. Critical factors for sub-supplier management: a sustainable food supply chains perspective. International Journal of Production Economics 152: 159-173.

Grunert, K.G., L. Fruensgaard Jeppesen, K. Risom Jespersen, A.M. Sonne, K. Hansen, T. Trondsen and J.A. Young. 2005. Market orientation of value chains: a conceptual framework based on four case studies from the food industry. European Journal of Marketing 39(5-6): 428-455.

Gulati, R., N. Nohria and A. Zaheer. 2000. Strategic Networks. Strategic Management Journal 21(3): 203-215.

Haasis, H.D, H.J Kreowski and B. Scholz-Reiter. 2008. Dynamics in logistics. In: Proceedings of the First International Conference LDIC. August, 2000. Bremen, Germany.

Hair, J.F., W. Black, B. Babin and R. Anderson. 2010. Multivariate data analysis: a global perspective, $7^{\text {th }}$ edition. Pearson Education, Hoboken, NJ, USA.

Han, S.L., D.T. Wilson and S.P. Dant. 1993. Buyer-supplier relationships today. Industrial Marketing Management 22(4): 331-338.

Hastings, K., J. Howieson and M. Lawley. 2016. Creating value chains: the role of relationship development. British Food Journal 118(6): 1384-1406.

Hewett, K., R.B. Money and S. Sharma. 2002. An exploration of the moderating role of buyer corporate culture in industrial buyer-seller relationships. Journal of the Academy of Marketing Science 30(3): 229-239.

Homburg, C. and B. Rudolph. 2001. Customer satisfaction in industrial markets: dimensional and multiple role issues. Journal of Business Research 52(1): 15-33.

Hu, L. and P.M. Bentler. 1999. Cutoff criteria for fit indexes in covariance structure analysis: conventional criteria versus new alternatives. Structural Equation Modeling. A Multidisciplinary Journal 6(1): 1-55

Jain, M., S. Khalil, W.J. Johnston and J.M.S. Cheng. 2013. The performance implications of power-trust relationship: the moderating role of commitment in the supplier-retailer relationship. Industrial Marketing Management 43(2): 312-321. 
Johnston, D.A., D.M. McCutcheon, F.I. Stuart and H. Kerwood. 2004. Effects of supplier trust on performance of cooperative supplier relationships. Journal of Operations Management 22(1): 23-38.

Joshi, S.P., P. Shitole, R. Chavan and P. Joshi. 2018. Strategies for buyer supplier relationship improvement: scale development and validation. Procedia Manufacturing 20: 470-476.

Kahneman, D. 2011. Thinking, fast and slow. Farrar, Straus and Giroux, New York, NY, USA.

Kannan, V.R. and K. Choon Tan. 2006. Buyer-supplier relationships: the impact of supplier selection and buyer-supplier engagement on relationship and firm performance. International Journal of Physical Distribution \& Logistics Management 36(10): 755-775.

Kannan, V.R. and K.C. Tan. 2002. Supplier selection and assessment: their impact on business performance. Journal of Supply Chain Management 38(3): 11-21.

Kim, K.K., S.-H. Park, S.Y. Ryoo and S.K. Park. 2010. Inter-organizational cooperation in buyer-supplier relationships: both perspectives. Journal of Business Research 63(8): 863-869.

Kim, K.T., J.S. Lee and S.Y. Lee. 2017. Chain reactions of a collaborative buyer-supplier relationship: the mediating role of relationship quality on innovation performance. Total Quality Management and Business Excellence 43(2): 1-19.

Kroll, M., P. Wright and R.A. Heiens. 1999. The contribution of product quality to competitive advantage: impacts on systematic variance and unexplained variance in returns. Strategic Management Journal 20(4): 375-384.

Kull, A.J., J.A. Mena and D. Korschun. 2016. A resource-based view of stakeholder marketing. Journal of Business Research 69(12): 5553-5560.

Kumar, N., L.K. Scheer and J.B. Steenkamp.1998. Interdependence, punitive capability and the reciprocation of punitive actions in channel relationships. Journal of Marketing Research 35(2): 225-235.

Kumar, N., L.K. Scheer and J.B.E. Steenkamp. 1995a. The effects of perceived interdependence on dealer attitudes. Journal of Marketing Research 32(3): 348-356.

Kumar, N., L.K. Scheer and J.B.E. Steenkamp. 1995b. The effects of supplier fairness on vulnerable resellers. Journal of Marketing Research 32(1): 54-65.

Laaksonen, T., T. Jarimo and H.I. Kulmala. 2009. Cooperative strategies in customer-supplier relationships: the role of interfirm trust. International Journal of Production Economics 120(1): 79-87.

Lages, C., C.R. Lages and L.F. Lages. 2005. The RELQUAL scale: a measure of relationship quality in export market ventures. Journal of Business Research 58(8): 1040-1048.

Lambert, D.M. 2006. Supply chain management: processes, partnerships, performance. Supply Chain Management Institute, Sarasota, FL, USA.

Lascelles, D.M. and B.G. Dale. 1989. The buyer-supplier relationship in total quality management. Journal of Purchasing \& Materials Management 25(2): 10-20.

Lechner, C. and M. Dowling. 2003. Firm networks: external relationships as sources for the growth and competitiveness of entrepreneurial firms. Entrepreneurship and Regional Development 15(1): 1-26.

Lees, N. and C. Saunders. 2015. Maximising export returns (MER): communicating New Zealand's credence attributes to international consumers. Lincoln University Agricultural Economics Research Unit, Christchurch, New Zealand.

Lees, N.J. and P. Nuthall. 2015. Case study analysis on supplier commitment to added value agri-food supply chains in New Zealand. Agricultural and Food Economics 3(1): 1-16.

Li, D., X. Wang, H.K. Chan and R. Manzini. 2014. Sustainable food supply chain management. International Journal of Production Economics 152: 1-8.

Li, W., P.K. Humphreys, A.C. Yeung and T.C.E. Cheng. 2012. The impact of supplier development on buyer competitive advantage: a path analytic model. International Journal of Production Economics 135(1): 353-366.

Lindeman, M., L. Sundvik and P. Rouhiainen. 1995. Under or overestimation of self? Person variables and self-asssessment accuracy in work settings. Journal of Social Behavior and Personality 10(1): 123.

Liu, Y., C. Su, Y. Li and T. Liu. 2010. Managing opportunism in a developing interfirm relationship: the interrelationship of calculative and loyalty commitment. Industrial Marketing Management 39(5): 844-852. 
Matopoulos, A., M. Vlachopoulou, V. Manthou and B. Manos. 2007. A conceptual framework for supply chain collaboration: empirical evidence from the agri-food industry. Supply Chain Management: An International Journal 12(3): 177-186.

Micheels, E.T. and H.R. Gow. 2011. The moderating effects of trust and commitment on market orientation, value discipline clarity and firm performance. Agribusiness 27(3): 360-378.

Mishra, A.K. 1996. Organizational responses to crisis: trust in organizations. Frontiers of Theory and Research 3(5): 261-287.

Morgan, R.M. and S. Hunt. 1994. The commitment-trust theory of relationship marketing. Journal of Marketing 58(3): 20-38.

Morgan, R.M. and S. Hunt. 1999. Relationship-based competitive advantage: the role of relationship marketing in marketing strategy. Journal of Business Research 46(3): 281-290

Nahapiet, J. and S. Ghoshal. 1998. Social capital, intellectual capital and the organizational advantage. Academy of Management Review 23(2): 242-266.

Nooteboom, B. 2000. Trust as governance device. In: M. Casson and A. Godley (eds.) Studies in economic ethics and philosophy. Springer-Verlag, Berlin, Germany, pp. 44-68.

Nyaga, G.N. and J.M. Whipple. 2011. Relationship quality and performance outcomes: achieving a sustainable competitive advantage. Journal of Business Logistics 32(4): 345-360.

Palmatier, R.W., R.P. Dant, D. Grewal and K.R. Evans. 2006. Factors influencing the effectiveness of relationship marketing: a meta-analysis. Journal of Marketing 70(4): 136-153.

Parsons, A.L. 2002. What determines buyer-seller relationship quality? An investigation from the buyer's perspective. Journal of Supply Chain Management 38(1): 4-12.

Poore, J. and T. Nemecek. 2018. Reducing food's environmental impacts through producers and consumers. Science 360(6392): 987-992.

Poppo, L., K.Z. Zhou and J.J. Li. 2016. When can you trust trust? Calculative trust, relational trust and supplier performance. Strategic Management Journal 37(4): 724-741.

Rábade, L.A. and J.A. Alfaro. 2006. Buyer-supplier relationship's influence on traceability implementation in the vegetable industry. Journal of Purchasing and Supply Management 12(1): 39-50.

Reagans, R. and B. McEvily. 2003. Network structure and knowledge transfer: the effects of cohesion and range. Administrative Science Quarterly 48(2): 240-267.

Reed, R., D.J. Lemak and N.P. Mero. 2000. Total quality management and sustainable competitive advantage. Journal of Quality Management 5(1): 5-26.

Rubin, E., Y.A. Argyris and I. Benbasat. 2017. Consumers'trust in price-forecasting recommendation agents. Paper presented at International Conference on HCI in Business, Government and Organizations. July 9-14, 2017. Vancouver, BC, Canada.

Rueda, X., R.D. Garrett and E.F. Lambin. 2017. Corporate investments in supply chain sustainability: selecting instruments in the agri-food industry. Journal of Cleaner Production 142: 2480-2492.

Ruekert, R.W. and G.A. Churchill Jr. 1984. Reliability and validity of alternative measures of channel member satisfaction. Journal of Marketing Research 21(2): 226-233.

Sako, M. and S. Helper. 1998. Determinants of trust in supplier relations: evidence from the automotive industry in Japan and the United States. Journal of Economic Behavior and Organization 34(3): 387-417.

Schmidt, O., S. Padel and L. Levidow. 2012. The bio-economy concept and knowledge base in a public goods and farmer perspective. Bio-Based and Applied Economics 1(1): 47-63.

Schulze, B., A. Spiller and L. Theuvsen. 2006. More trust instead of more vertical integration in the German pork production? Empirical evidence and theoretical considerations. In: $99^{\text {th }}$ Seminar of the European Association of Agricultural Economists. February 8-10, 2006. Bonn, Germany.

Shih, T.Y. 2017. An empirical study of food and beverage chains' internationalisation: advancing intangible resource theory and research. European Journal of International Management 11(6): 660-687.

Shin, H., D.A. Collier and D.D. Wilson. 2000. Supply management orientation and supplier/buyer performance. Journal of Operations Management 18(3): 317-333.

Stank, T., M. Crum and M. Arango. 1999. Benefits of interfirm coordination in food industry supply chains. Journal of Business Logistics 20(2): 21-41. 
Steiner, B., K. Lan, J. Unterschultz and P. Boxall. 2017. Applying the resource-based view to alliance formation in specialized supply chains. Journal of Strategy and Management 10(3): 262-292.

Stevenson, G., K. Clancy, R. King, L. Lev, M. Ostrom and S. Smith. 2016. Midscale food value chains: an introduction. Journal of Agriculture, Food Systems and Community Development 1(4): 27-34.

Tavakol, M. and R. Dennick. 2011. Making sense of Cronbach's alpha. International Journal of Medical Education 2: 53.

Touboulic, A. and H. Walker. 2015. Love me, love me not: a nuanced view on collaboration in sustainable supply chains. Journal of Purchasing and Supply Management 21(3): 178-191.

Trienekens, J., M. van Velzen, N. Lees, C. Saunders and S. Pascucci. 2018. Governance of market-oriented fresh food value chains: export chains from New Zealand. International Food and Agribusiness Management Review 21(2): 249-268.

Trienekens, J.H., P. Wognum, A.J. Beulens and J.G. van der Vorst. 2012. Transparency in complex dynamic food supply chains. Advanced Engineering Informatics 26(1): 55-65.

Tsai, W. and S. Ghoshal. 1998. Social capital and value creation: the role of intrafirm networks. Academy of Management Journal 41(4): 464-476.

Ulaga, W. and A. Eggert. 2001. Developing a standard scale of relationship value in business markets. In: Proceedings of the $17^{\text {th }}$ Annual IMP Conference. September 9-11, 2001. Oslo, Norway.

Ulaga, W. and A. Eggert. 2006. Relationship value and relationship quality: broadening the nomological network of business-to-business relationships. European Journal of Marketing 40(3-4): 311-327.

Van der Vorst, J.G.A.J., S. Van Dongen, S. Nouguier and R. Hilhorst. 2002. E-business initiatives in food supply chains; definition and typology of electronic business models. International Journal of Logistics 5(2): 119-138.

Villena, V.H., E. Revilla and T.Y. Choi. 2011. The dark side of buyer-supplier relationships: a social capital perspective. Journal of Operations Management 29(6): 561-576.

Whipple, J.M., R. Wiedmer and K.K. Boyer. 2015. A dyadic investigation of collaborative competence, social capital and performance in buyer-supplier relationships. Journal of Supply Chain Management 51(2): 3-21.

Willett, W., J. Rockström, B. Loken, M. Springmann, T. Lang, S. Vermeulen, T. Garnett, D. Tilman, F. DeClerck and A. Wood. 2019. Food in the anthropocene: the EAT-Lancet commission on healthy diets from sustainable food systems. The Lancet 393(10170): 447-492.

Wilson, D.T. 1995. An integrated model of buyer-seller relationships. Journal of the Academy of Marketing Science 23(4): 335-345.

Wognum, P.N., H. Bremmers, J.H. Trienekens, J. van der Vorst and J.M. Bloemhof. 2011. Systems for sustainability and transparency of food supply chains: current status and challenges. Advanced Engineering Informatics 25(1): 65-76.

Wu, C.-C., Y. Huang and C.L. Hsu. 2014. Benevolence trust: a key determinant of user continuance use of online social networks. Information Systems and e-Business Management 12(2): 189-211.

Yang, F. and X. Zhang. 2017. The impact of sustainable supplier management practices on buyer-supplier performance: an empirical study in China. Review of International Business and Strategy 27(1): 112-132.

Young, L.M. and J.E. Hobbs. 2002. Vertical linkages in agri-food supply chains: changing roles for producers, commodity groups and government policy. Review of Agricultural Economics 24(2): 428-441.

Ziggers, G. and J. Trienekens. 1999. Quality assurance in food and agribusiness supply chains: developing successful partnerships. International Journal of Production Economics 60: 271-279. https://doi. org/10.1016/S0925-5273(98)00138-8 
